\title{
CERDAS BERPOLITIK: LITERASI MEDIA ANTI HOAX KELURAHAN DOMPAK KECAMATAN BUKIT BESTARI KOTA TANJUNGPINANG
}

\section{Political Intelligence: Anti-Hoax Media Literacy in Dompak Village, Bukit Bestari District, Tanjungpinang City}

\author{
Novi Winarti ${ }^{1 *}$, Nanik Rachmawati ${ }^{1}$, Ardi Putra ${ }^{1}$ \\ ${ }^{1}$ Jurusan Ilmu Pemerintahan, Fakultas Ilmu Sosial dan Ilmu Politik, Universitas Maritim Raja \\ Ali Haji, Tanjungpinang \\ *Korespondensi : noviwinarti@umrah.ac.id
}

\begin{abstract}
ABSTRAK
Saat ini hampir semua lapisan masyarakat menggunakan literasi media, khususnya media digital. Dengan partisipasi politik masyarakat Dompak yang tinggi, harus diselaraskan dengan pengetahuan dan kecerdasan penggunaan media. Oleh karena itu melalui kegiatan Pengabdian kepada Masyarakat ini, dilakukan dalam beberapa tahap. Pertama, wawancara awal kepada Aparat Kelurahan Dompak. Tahap kedua yakni pemberian buku saku kepada masyarakat Kelurahan Dompak, melalui pihak Kelurahan. Ketiga, dilakukan pendampingan terhadap masyarakat.Respon masyarakat Kelurahan Dompak sangat positif dengan dibagikannya buku saku dan pendampingan yang dilaksanakan, sehingga masyarakat mampu melawan hoax di dalam politik dengan literasi media. Pada akhirnya, apa yang menjadi hal yang salah selama ini dalam melaksanakan proses demokratisasi, yakni adanya berita-berita hoax saat pemilukada, tidak mempengarui pilihan politik masyarakat Kelurahan Dompak.
\end{abstract}

Kata Kunci: Literasi, Media, Hoax

\begin{abstract}
Nowdays, almost all levels of society use media literacy, especially digital media. High political participation of the Dompak Village community, it must be aligned with the knowledge and intelligence of using media. Therefore, through this community service activity, it is carried out in several stages. First, the initial interview with the Dompak Village Apparatus. The second stage is the provision of pocket books to the Dompak Village community, through the government authority. Third, providing assistance to the community. The response of the Dompak Village community was very positive with the distribution of pocket books and assistance carried out, so that the community was able to fight hoaxes in politics with media literacy. In the end, what has been wrong so far in carrying out the democratization process, namely the existence of hoax news during the post-conflict local election, does not affect the political choices of the Dompak Village community.
\end{abstract}

Keywords: Literacy, Media, Hoax 


\section{PENDAHULUAN}

Dewasa ini dunia digital bukanlah merupakan hal yang asing. Hampir setiap waktu dan tidak terkecuali di masyarakat manapun dapat mengakses internet. Yang terjadi kemudian adalah begitu terbukanya data dan berita yang dapat diakses oleh siapa saja. Salah satu aspek yang banyak digunakan di dunia digital saat ini adalah media sosial. Menurut Nasrullah (2015:11) media sosial adalah medium di internet yang memungkinkan pengguna merepresentasikan dirinya maupun berinteraksi, bekerjasama, berbagi, berkomunikasi dengan pengguna lain, dan membentuk ikatan sosial secara virtual.

Jonah Berger dan Katherine Milkman (di dalam Struhar, 2014) menuliskan bahwa berita-berita yang dibagikan secara viral melalui media sosial adalah berita yang mampu membangkitkan emosi positif atau negatif yang sangat kuat (high-arousal emotions). Sehingga tidak menutup kemungkinan dalam penggunaan media sosial, pengguna tidak menggunakan logika, melainkan hanya dipengaruhi oleh emosi.

Gumilar dkk (2017: 35) menyatakan bahwa pemberitaan bohong atau palsu (hoax) menjadi fokus perhatian terutama di media online. Banjir informasi menyulitkan pengguna untuk menentukan informasi yang benar dengan informasi palsu. Informasi palsu ini menjadi bagian dari konflik sehingga masing-masing mengklaim informasi yang disampaikan oleh kelompoknya adalah yang benar sedangkan lawannya menyampaikan informasi palsu.

Hoax merupakan informasi yang direkayasa untuk menutupi informasi sebenarnya. Dengan kata lain hoax juga bisa diartikan sebagai upaya penutarbalikan fakta menggunakan informasi yang seolah-olah meyakinkan tetapi tidak dapat diverifikasi kebenarannya. Hoax juga bisa diartikan sebagai tindakan mengaburkan informasi yang sebenarnya, dengan cara membanjiri suatu media dengan pesan yang salah agar bisa menutupi pesan yang benar. Tujuan dari hoax yang disengaja adalah membuat masyarakat merasa tidak aman, tidak nyaman, dan kebingungan. Dalam kebingungan, masyarakat akan mengambil keptusan yang lemah, tidak meyakinkan, dan bahkan salah. Perkembangan hoax di media sosial semula dilakukan untuk sarana perisakan. Namun, perkembangan selanjutnya, para spin doctor politik melihat efektivitas hoax sebagai alat black campaign di pesta demokrasi yang mempengaruhi persepsi pemilih (Indonesia Mendidik, 2016).

Survey yang dilakukan oleh Fahmi (dikutip oleh Gumilar dkk, 2017: 36) mengungkap 92,40\% hoax di Indonesia diakui tersebar melalui media sosial (facebook, twitter, Instagram dan Path), berturut-turut $62,80 \%$ hoax tersebar melalui aplikasi chatting (whatsapp, line, telegram) dan menempati nomor tiga, berturut-turut $34,90 \%$ hoax tersebar melalui situs web. Sedangkan bila didasarkan format-nya hoax, $62,10 \%$ yang tesebar berbentuk tulisan, sedangkan $37,50 \%$ berbentuk gambar dua dimensi. Riset Fahmi lebih jauh menemukan hoax paling populer di Indonesia 91,80\% merupakan isu sosial politik, yang secara spesifik membahas terkait Pemilukada dan Kebijakan atau Kinerja Pemerintah. Menyusul berturut-turut di nomor dua, yaitu isu SARA (Suku Agama Ras dan Antargolongan) sebanyak $88,60 \%$, berada di nomor ketiga, yaitu isu kesehatan.

Hasil riset diatas mengemukakan bahwa isu hoax yang paling populer adalah terkait Pemilukada dan Kebijakan atau Kinerja Pemerintah. Dalam partisipasi politik, informasi yang selalu diterima oleh suatu masyarakat akan menentukan bagaimana pilihan politik yang diambil. Artinya, jika isu hoax yang paling tinggi adalah mengenai Pemilukada dan Kebijakan atau Kinerja Pemerintah maka tidak menutup kemungkinan pilihan masyarakat dalam politik juga akan dipengaruhi oleh berita dan isu hoax.

Masyarakat mitra di dalam kegiatan Pengabdian ini yaitu masyarakat Kelurahan Dompak Kecamatan Bukit Bestari di Kota 
Tanjungpinang. Hasil wawancara dengan tokoh masyarakat Kelurahan Dompak, mengemukakan bahwa masyarakat Dompak memiliki partisipasi politik yang tinggi. Dengan partisipasi politik yang tinggi ini sangat disayangkan apabila dipengaruhi oleh isu dan berita hoax yang saat ini sangat masif terjadi.

Pengabdian ini dilakukan karena beberapa alasan penting. Pertama, masyarakat kelurahan Dompak merupakan masyarakat yang sangat dinamis. Dalam era revolusi 4.0 ini, penggunaan internet sudah bergerak di segala lapisan masyarakat, tudak terkeculai masyarakat Kelurahan Dompak. Berdasarkan hasil penelitian yang dilakukan oleh Sophia dan Winarti tahun 2018 di Kota Tanjungpinang mengenai Pemetaan Penggunaan Media Online sebagai Saluran Politk pada Pemilukada Kota tnjungpinang tahun 2018, ditemukan bahwa sebanyak 207 dari 347 responden menggunakan media sosial Facebook di dalam mengakses pemberitaan dan informasi kontestan pemilukada. Selebihnya responden menggunakan instagram, twitter, line dan whatsapp. Artinya bahwa memang fenomena digitalisasi juga terjadi pada masyarakat Dompak.

Kedua, partisipasi politik masyarakat Kelurahan Dompak sangat tinggi. Dalam kajian budaya politik, budaya politik partisipatif merupakan budaya politik yang paling tinggi "kasta"-nya. Untuk mewujudkan demokratisasi secara substantif di ranah lokal, dengan adanya budaya politik partisipatif ini dapat diibaratkan dengan istilah "gayung bersambut". Oleh karena itu sangat penting apabila budaya politik partisipatif yang dimiliki oleh masyarakat Kelurahan Dompak diselaraskan dengan kecerdasan di dalam memperoleh berita dan fakta yang terkait dengan politik serta pemerintahan.

Dari beberapa hal yang dikemukakan di atas merunut pada sebuah kegiatan yang harus dilaksanakan untuk menyelaraskan partisipasi politik dengan kecerdasan di dalam literasi media. Sehingga partisipasi politik masyarakat Kelurahan Dompak dapat berkembang dengan lebih baik

Tingkat partisipasi politik yang tinggi di dalam masyarakat Kelurahan Dompak merupakan hal yang sangat positif dalam budaya politik di ranah lokal. Namun yang terjadi saat ini adalah begitu banyaknya isu dan berita terkait politik dan pemerintahan yang dipolitisasi. Sehingga yang muncul di sebagian besar pemberitaan dan isu di media sosial merupakan kebohongan belaka (hoax). Hal ini jika dibiarkan berlarut-larut hanya akan menghasilkan partisipasi yang tidak "sehat" di ranah lokal. Sehingga, muncul sebuah permasalahan yang harus diselesaikan, yakni bagaimana menumbuhkan literasi media anti hoax Kelurahan Dompak Kecamatan Bukit Bestari Kota Tanjungpinang?

\section{METODE}

Metode pengabdian yang akan digunakan dalam kegiatan pengabdian masyarakat ini yaitu dengan menggunakan metode diskusi dan sharing pengetahuan. Kegiatan tersebut akan diawali dari wawancara kepada Kepala Kelurahan Dompak dan beberapa tokoh masyarakat.

Kegiatan Pengabdian kepada Masyarakat ini akan dilanjutkan dengan diskusi dan sharing pengetahuan. Namun, diskusi yang semula akan dilaksanakan dengan masyarakat Kelurahan Dompak mengalami kendala Covid-19. Saat ini bencana non alam Covid-19 sedang mewabah hampir di seluruh belahan dunia, termasuk di Kota Tanjungpinang. Menjadi sangat riskan apabila melakukan kegiatan dengan mengumpulkan begitu banyak masyarakat. Hal tersebut menjadi pertimbangan pihak kelurahan (surat keterangan terlampir). Untuk keberlanjutan program yang telah dilakukan, tim pelaksana merangkum bahanbahan yang akan didiskusikan ke dalam sebuah buku saku. Buku saku yang telah ditulis oleh tim pelaksana pengabdian ini kemudian diserahkan kepada kelurahan untuk dibagikan kepada masyarakat. 
Setelah penyerahan buku saku, pendampingan kepada masyarakat Kelurahan Dompak akan dilakukan agar kegiatan Pengabdian Kepada Masyarakat ini mampu menggiring masyarakat Kelurahan Dompak sampai kepada paritisipasi politik yang jauh dari isu dan berita hoax. Setelah kegiatan Pengabdian Kepada Masyarakat selesai dilaksanakan akan ada evaluasi dari pihak yang melakukan pengabdian kepada masyarakat dengan cara melakukan komunikasi yang bersifat konsultatif sehingga kontribusi terhadap kemajuan paritisipasi politik masyarakat Kelurahan Dompak tetap berlanjut.

\section{HASIL DAN PEMBAHASAN}

Kegiatan Pengabdian Kepada Masyarakat yang dilakukan di Kelurahan Dompak telah dilaksanakan selama 7 (tujuh) bulan. Dalam kurun waktu tersebut telah dilaksanakan beberapa kegiatan, yakni wawancara, penyerahan buku saku dan pendampingan kepada masayarakat Kelurahan Dompak. Kegiatan dilaksanakan secara kontiniu sehingga tujuan program Pengabdian Kepada Mayarajat ini dapat dicapai semaksimal mungkin.

Pada tahap pertama, setelah dilakukan wawancara dengan aparat Kelurahan Dompak didapat informasi bahwa saat ini banyak sekali beredar berita-berita dan kabar mengenai dinamika Pemilukada Gubernur Provinsi Kepulauan Riau yang akan dilaksanakan pada bulan Desember 2020 mendatang. Kabar-kabar yang beredar dalam media massa maupun media online sangat beragam, mulai dari siapa yang akan menjadi pasangan bakal calon gubernur, identitas, bahkan latar belakang mereka. Karena sangat banyaknya informasi yang beredar, maka hampir tidak dapat dibedakan antara berita yang benar ataupun yang hoax.

Berdasarkan hasil pengamatan data monografi Kelurahan Dompak didapati pula angka partisipasi pendidikan yang rendah di Kelurahan Dompak. Rendahnya tingkat pendidikan juga akan mempengaruhi persepsi masyarakat terhadap informasiinformasi yang ada. Artinya, masyarakat yang memiliki tingkat pendidikan yang rendah akan mudah percaya dengan informasi yang diterima.

Setelah dilakukan wawancara dengan aparat kelurahan Dompak, tim pelaksana kegiatan pengabdian ini melanjutkan program kegiatan dengan merangkum apa yang akan dijadikan bahan diskusi dengan masyarakat kelurahan Dompak ke dalam sebuah Buku Saku, yakni sebagai berikut. Buku Saku yang ditulis berisikan 4 (empat) bab. Bab pertama menjelaskan tentang konsep dan definisi hoax. Lebih rinci, di dalam bab pertama ini dijelaskan mengenai apa itu hoax, jenis-jenis hoax dan apa dampak yang ditimbulkan dari penyebaran hoax. Pada bab kedua, dijelaskan mengenai ketentuan hokum dalam penyebaran hoax. Sementara bab ketiga, dibahas tentang eratnya hoax dengan kehidupan politik. Di dalam bab terakhir, diuraikan tentang langkah Melawan Hoax di dalam Politik dengan Literasi Media. Buku Saku yang telah selesai ditulis kemudian diserahkan kepada aparat Kelurahan Dompak untuk diberikan kepada masyarakat.

Setelah penyerahan buku saku kepada aparat Kelurahan Dompak dilakukan, buku saku tersebut kemudian dibagikan kepada masyarakat sekitar yang ada di Kelurahan Dompak. Melalui buku saku tersebut, masyarakat menerima edukasi bagaimana literasi media anti hoax, khususnya dalam menyambut pesta demokrasi pemilukada Gubernur Kepulauan Riau tahun 2020. Hal ini sangat membantu masyarakat dalam proses demokratisasi di ranah lokal. Masyarakat Kelurahan Dompak dikenal dengan masyarakat yang tingkat partisipasi politiknya tinggi, maka gayungpun bersambut saat literasi media anti hoax diberikan kepada masyarakat.

Tahapan berikutnya yang dilakukan yaitu pendampingan kepada masyarakat Kelurahan Dompak. Pendampingan dilakukan agar buku saku yang telah diberikan kepada masyarakat dapat memberikan manfaat yang positif dan 
berkelanjutan di dalam kehidupan politik lokal masyarakat Kelurahan Dompak. Pendampingan dilakukan beberapa kali dengan masyarakat yang berbeda-beda agar pemahaman terhadap literasi media anti hoax benar-benar menguat di ranah grassroot. Dalam proses pendampingan, diperkuat lagi pemahaman tentang literasi media anti hoax yang telah dibahas di dalam buku saku kepada masyarakat. Di antaranya yakni mengenai apa itu hoax, jenis-jenis hoax dan apa dampak yang ditimbulkan dari penyebaran hoax. Selain itu, juga dijelaskan mengenai ketentuan hukum dalam penyebaran hoax serta eratnya hoax dengan kehidupan politik. Hal yang kemudian dibahas juga yakni tentang langkah melawan hoax di dalam politik dengan literasi media.

Masyarakat Kelurahan Dompak sangat antusias dengan dibagikannya buku saku dan pendampingan yang dilaksanakan. Sehingga apa yang menjadi hal yang salah selama ini dalam melaksanakan proses demokratisasi, yakni adanya berita-berita hoax saat pemilukada, tidak mempengarui pilihan politik masyarakat Kelurahan Dompak.

\section{KESIMPULAN}

Media yang sehat sangat diperlukan pada masa-masa kontestasi, tetapi sayangnya hal tersebut merupakan hal yang sangat sulit diwujudkan. Berbagai macam berita hoax sering beredar di masyarakat, tidak terkecuali masyarakat Kelurahan Dompak. Berangkat dari kondisi tersebut, maka dilaksanakan kegiatan pengabdian kepada masyarakat ini dengan serangkaian kegiatan, yakni wawancara dengan apparat kelurahan, pembagian buku saku kepada masyarakat dan pendampingan kepada mayarakat Kelurahan Dompak dalam literasi media anti hoax.

Respon masyarakat Kelurahan Dompak sangat positif dengan dibagikannya buku saku dan pendampingan yang dilaksanakan, sehingga masyarakat mampu melawan hoax di dalam politik dengan literasi media. Pada akhirnya, apa yang menjadi hal yang salah selama ini dalam melaksanakan proses demokratisasi, yakni adanya berita-berita hoax saat pemilukada, tidak mempengarui pilihan politik masyarakat Kelurahan Dompak.

Dengan adanya kegiatan pengabdian ini diharapkan masyarakat Kelurahan Dompak dapat menyaring berita yang beredar seputar kegiatan pemilukada Gubernur Kepulauan Riau tahun 2020 ini, sehingga partisipasi masyarakat di dalam arena pemilukada kelak benar-benar memberikan manfaat bagi proses demokratisasi.

\section{DAFTAR PUSTAKA}

Gumilar, Gumgum dkk. Literasi Media: Cerdas Menggunakan Media Sosial Dalam Menanggulangi Berita Palsu (Hoax) Oleh Siswa SMA. Jurnal Pengabdian Kepada Masyarakat ISSN 1410 - 5675. Vol. 1, No. 1, Februari 2017: $35-40$

Indonesia Mendidik. (2016). Kulwap: Melek Literasi di Era Digital. Retrieved January 12, 2017, from Indonesia Mendidik: http://indonesiamendidik. com/tag/antihoax

Nasrullah, Rulli. 2015. Media Sosial: Perspektif Komunikasi, Budaya, dan Sosioteknologi. Simbiosa Rekatama Media.

Sophia, Uly dan Novi Winarti. Pemetaan Media Massa Dan Media Sosial Sebagai Saluran Komunikasi Politik Pada Pemilukada Kota Tanjungpinang 2018. Jurnal Riset Komunikasi. Volume 2 Nomor 2 Agustus 2019: 184-201

Struhar, C. (2014, February 12). The Facebook Effect on the News. The Atlantic. Retrieved March 29, 2016, from www.theatlantic.com/business/ archive/2014/02/the-facebook-effect-onthe-news/283746. 